\title{
Evaluation of protein fractions in the serum as potential determinants of risk of the recurrent miscarriages
}

\author{
Corresponding author: \\ Karina Chmielarz, Department of \\ Laboratory Medicine, Nicolaus \\ Copernicus University, Collegium \\ Medicum in Bydgoszcz, Poland, \\ ul. M. Curie-Skłodowskiej 9 , \\ 85-094 Bydgoszcz \\ phone: +48 694717603 \\ e-mail: karina.chmielarz@gmail.com
}

Medical Research Journal 2018; Volume 3, Number 3, 142-147 10.5603/MRJ.2018.a0024 Copyright (C) 2018 Via Medica ISSN 2451-2591

\begin{abstract}
Background: According to the World Health Organization, recurrent miscarriage is defined as the loss of 3 or more consecutive early pregnancies, affecting $0.5 \%$ to $3 \%$ of pregnant women. According to clinical practice, it is recommended to perform a diagnostic investigation after two consecutive miscarriages in order to identify the reason for miscarriages. Despite numerous investigations, around $40-60 \%$ of recurrent pregnancy losses is still idiopathic. In the conducted research, the utility of the determination of serum protein fractions in the diagnosis of recurrent miscarriage was evaluated.

Material and methods: The study group consisted of 20 women (aged $36.12 \pm 3.53$ ) with recurrent miscarriage of undetermined aetiology. The control group comprised 20 non-pregnant women (aged $35.7 \pm 3.28$ ) who had given birth to healthy children at least twice. Blood serum collected by venipuncture was examined. Serum protein fractions were separated by electrophoresis in the SDS PAGE buffer system using a Mini PROTEAN 3 cell device. BioRad SDS PAGE Molecular Weight Standards covering a mass range of 6.5-200 kDa were used as a reference.

Results: Electrophoretic separation revealed 71 protein fractions of 10 to $240 \mathrm{kDa}$. It was observed that protein fractions with molecular weights of $27,36,53$ and $172 \mathrm{kDa}$ were present more frequently in serum from women in the control group. Protein fractions of 28, 132 and $188 \mathrm{kDa}$ predominated among patients in the experimental group. This research has demonstrated that the number of 53 and $172 \mathrm{kDa}$ protein fractions decreased with the number of miscarriages.

Conclusions: It is suggested that individual protein fractions may increase the risk of a miscarriage. Key words: recurrent miscarriage, protein fractions, abortion, pregnancy, electrophoresis
\end{abstract}

Med Res J 2018; 3 (3): 142-147

\section{Introduction}

Although the issue of recurrent miscarriages was noticed about 25 years ago, studies on the early diagnosis of this pathology are still insufficient. According to the World Health Organization (WHO), recurrent miscarriage is defined as the loss of 3 or more consecutive early pregnancies (before 12 weeks of gestation), affecting $1 \%$ to $2 \%$ of reproductive-age women [1]. According to clinical practice, it is recommended to perform a diagnostic investigation after two consecutive miscarriages in order to identify the reason of failure [2]. The commonest complication of pregnancy is the spontaneous miscarriage. It pertains to approx. $15 \%$ of clinically detected pregnancies, of which about $80 \%$ are early miscarriages occurring in the first 12 weeks of gestation [4]. Recurrent pregnancy loss accounts for $5 \%$ of all spontaneous abortions and is the cause of $0.4-0.8 \%$ of all pregnancy losses [3].

The risk of miscarriage correlates with gestational age. The highest incidence of pregnancy loss occurs before implantation and accounts for approx. $50 \%$ of all miscarriages. Referring to epidemiological studies, it can be stated that the course of the first pregnancy has an impact on the succeeding ones. The probability to experience a pregnancy loss for women, who have never been pregnant or already have a child, amounts to only $5 \%$. Contrary to this, women who experienced miscarriage once, have a $13-20 \%$ chance of consecutive pregnancy loss. The risk of miscarriage increases with the number of miscarriages, where three or more amount to as much as $30-45 \%$ chance of loss [5]. Despite several earlier performed studies, only the 
antiphospholipid syndrome, uterine structural anomalies and chromosomal factors amongst parents are confirmed to be causing recurrent miscarriages and can be identified in up to $40 \%$ of cases [6]. Notwithstanding, more than half of the cases of idiopathic abortions with unexplained etiology still remain vague [7].

Currently, there is a need for elaboration of a specific test that could be useful in early routine laboratory diagnosis of the recurrent miscarriage risk. The test should allow recognition of the factors underlying the pathology and enable quick diagnosis leading to the implementation of effective therapy.

\section{Materials and methods}

\section{Study design and performance}

A permission to conduct this study was obtained from the Bioethics Committee of the Ludwik Rydygier Collegium Medicum, of Nicolaus Copernicus University in Toruń. The study involved 40 women aged 29 to 44 years $(35.89 \pm 3.4)$ admitted to Department of Obstetrics, Gynecology and Gynecological Oncology in University Hospital No. 2 in Bydgoszcz. Based on a medical history taken from each patient, the existence of comorbid chronic diseases and infections was excluded and also information on smoking during pregnancy was obtained.

The study group consisted of 20 women aged 29 to $44(36.12 \pm 3.53)$ with recurrent miscarriages. This group was divided according to the number of miscarriages, as well as the fact of smoking cigarettes during pregnancy (Table 1).

The reference group consisted of 20 non-pregnant women aged 30 to $41(35.7 \pm 3.28)$ who had given vaginal birth to healthy children at least twice.

\section{Blood sampling and laboratory analyses}

The $10 \mathrm{ml}$ blood samples were collected by venipuncture into test tubes without anticoagulant. The blood from women with habitual abortions was taken at least 6 weeks after the miscarriage, in order to eliminate the impact of puerperium. The blood samples were centrifuged for 10 minutes at $3000 \mathrm{rpm}$ to obtain serum. Sera were divided into $200 \mu \mathrm{l}$ aliquots and stored at $-70^{\circ}$ $\mathrm{C}$ until assays were performed.

\section{Statistical analysis}

Statistical analysis was performed using Excel 2013 of the Microsoft Office 2013 package and Statistica 13.1 by StatSoft, Inc. (2010). The Mann-Whitney $U$ test with the continuity correction, the Kruskal-Wallis test, and the analysis of contingency tables was used to assess differences between groups.

\section{Results}

A comparative analysis of serum protein fractions isolated after gel-electeophoresis from women with recurrent miscarriages and healthy ones was done. After gel-electrophoresis 71 protein fractions with molecular weights ranging from 10 to $240 \mathrm{kDa}$ were obtained. The majority of separated protein fractions were present in the serum from women in both groups. The most evident differences, however, were found for the fractions of 27, 28, 36,53, 132, 172 and $188 \mathrm{kDa}$ (Table 2). In addition, statistical analysis of protein fractions was made, considering tobacco smoking in the study group. Among the patients with recurrent miscarriages, 8 women (40\%) were smokers and remaining 12 (60\%) were non-smokers. The largest differences between smokers

Table 1. Characteristics of the study group and reference group

\begin{tabular}{|c|c|c|c|}
\hline Parameter & & Study group & Reference group \\
\hline $\begin{array}{l}\text { Number of patients } \\
\mathrm{N}(\%)\end{array}$ & & $20(100 \%)$ & $20(100 \%)$ \\
\hline Age $(X \pm S D)$ & & $29-44(36,12 \pm 3,53)$ & $30-41(35,70 \pm 3,28)$ \\
\hline $\begin{array}{l}\text { Successful pregnancy } \\
N(\%)\end{array}$ & & $11(18 \%)$ & $40(100 \%)$ \\
\hline \multirow[t]{2}{*}{ Miscarriage } & Early (<12 week ) & $48(77,42 \%)$ & $0(\%)$ \\
\hline & Late (>12 week) & $14(22,58 \%)$ & \\
\hline \multirow[t]{2}{*}{ Number of miscarriage } & $\begin{array}{l}3 \text { miscarriage } \\
\mathrm{N}(\%)\end{array}$ & $18(90 \%)$ & $0(0 \%)$ \\
\hline & $\begin{array}{l}4 \text { miscarriage } \\
\mathrm{N}(\%)\end{array}$ & $2(10 \%)$ & $0(0 \%)$ \\
\hline Smoking N (\%) & & $8(40 \%)$ & $0(0 \%)$ \\
\hline
\end{tabular}


Table 2. Comparison of the occurence of protein fractions in the blood serum of women in the study group and the reference group

\begin{tabular}{|c|c|c|c|c|c|c|c|c|c|c|c|}
\hline \multirow[t]{2}{*}{ No } & \multirow[t]{2}{*}{$\begin{array}{l}\text { The molecular } \\
\text { weight [kDa] }\end{array}$} & \multicolumn{2}{|c|}{ Study group } & \multicolumn{2}{|c|}{$\begin{array}{l}\text { Reference } \\
\text { group }\end{array}$} & \multirow[t]{2}{*}{ No } & \multirow[t]{2}{*}{$\begin{array}{l}\text { The molecular } \\
\text { weight [kDa] }\end{array}$} & \multicolumn{2}{|c|}{ Study group } & \multicolumn{2}{|c|}{$\begin{array}{l}\text { Reference } \\
\text { group }\end{array}$} \\
\hline & & $\mathbf{N}$ & $\%$ & $\mathbf{N}$ & $\%$ & & & $\mathbf{N}$ & $\%$ & $\mathbf{N}$ & $\%$ \\
\hline 1. & 10 & 18 & $90 \%$ & 20 & $100 \%$ & 37. & 88 & 18 & $90 \%$ & 12 & $60 \%$ \\
\hline 2. & 11 & 6 & $30 \%$ & 11 & $55 \%$ & 38. & 90 & 0 & $0 \%$ & 0 & $0 \%$ \\
\hline 3. & 12 & 10 & $50 \%$ & 6 & $30 \%$ & 39. & 92 & 0 & $0 \%$ & 1 & $5 \%$ \\
\hline 4. & 14 & 2 & $10 \%$ & 0 & $0 \%$ & 40. & 96 & 4 & $20 \%$ & 11 & $55 \%$ \\
\hline 5. & 15 & 19 & $95 \%$ & 20 & $100 \%$ & 41. & 98 & 0 & $0 \%$ & 1 & $5 \%$ \\
\hline 6. & 16 & 3 & $15 \%$ & 1 & $5 \%$ & 42. & 100 & 9 & $45 \%$ & 4 & $20 \%$ \\
\hline 7. & 17 & 10 & $50 \%$ & 0 & $0 \%$ & 43. & 107 & 4 & $20 \%$ & 4 & $20 \%$ \\
\hline 8. & 19 & 6 & $30 \%$ & 9 & $45 \%$ & 44. & 116 & 10 & $50 \%$ & 3 & $15 \%$ \\
\hline 9. & 20 & 0 & $0 \%$ & 0 & $0 \%$ & 45. & 127 & 1 & $5 \%$ & 5 & $25 \%$ \\
\hline 10. & 22 & 19 & $95 \%$ & 18 & $90 \%$ & 46. & 130 & 0 & $0 \%$ & 2 & $10 \%$ \\
\hline 11. & 23 & 0 & $0 \%$ & 0 & $0 \%$ & 47. & 132 & 12 & $60 \%$ & 4 & $20 \%$ \\
\hline 12. & 24 & 1 & $5 \%$ & 0 & $0 \%$ & 48. & 138 & 5 & $25 \%$ & 0 & $0 \%$ \\
\hline 13. & 25 & 0 & $0 \%$ & 0 & $0 \%$ & 49. & 140 & 1 & $5 \%$ & 2 & $10 \%$ \\
\hline 14. & 27 & 0 & $0 \%$ & 15 & $75 \%$ & 50. & 142 & 3 & $15 \%$ & 0 & $0 \%$ \\
\hline 15. & 28 & 17 & $85 \%$ & 1 & $5 \%$ & 51. & 144 & 2 & $10 \%$ & 3 & $15 \%$ \\
\hline 16. & 29 & 0 & $0 \%$ & 1 & $5 \%$ & 52. & 147 & 2 & $10 \%$ & 6 & $30 \%$ \\
\hline 17. & 32 & 0 & $0 \%$ & 0 & $0 \%$ & 53. & 150 & 3 & $15 \%$ & 7 & $35 \%$ \\
\hline 18. & 34 & 12 & $60 \%$ & 0 & $0 \%$ & 54. & 152 & 0 & $0 \%$ & 0 & $0 \%$ \\
\hline 19. & 36 & 0 & $0 \%$ & 20 & $100 \%$ & 55. & 157 & 7 & $35 \%$ & 0 & $0 \%$ \\
\hline 20. & 38 & 7 & $35 \%$ & 0 & $0 \%$ & 56. & 159 & 2 & $10 \%$ & 0 & $0 \%$ \\
\hline 21. & 40 & 0 & $0 \%$ & 2 & $10 \%$ & 57. & 160 & 11 & $55 \%$ & 3 & $15 \%$ \\
\hline 22. & 41 & 0 & $0 \%$ & 0 & $0 \%$ & 58. & 163 & 1 & $5 \%$ & 0 & $0 \%$ \\
\hline 23. & 42 & 0 & $0 \%$ & 0 & $0 \%$ & 59. & 168 & 2 & $10 \%$ & 0 & $0 \%$ \\
\hline 24. & 45 & 17 & $85 \%$ & 20 & $100 \%$ & 60. & 170 & 4 & $20 \%$ & 1 & $5 \%$ \\
\hline 25. & 48 & 4 & $20 \%$ & 0 & $0 \%$ & 61. & 172 & 4 & $20 \%$ & 17 & $85 \%$ \\
\hline 26. & 53 & 4 & $20 \%$ & 17 & $85 \%$ & 62. & 180 & 2 & $10 \%$ & 4 & $20 \%$ \\
\hline 27. & 56 & 10 & $50 \%$ & 3 & $15 \%$ & 63. & 182 & 0 & $0 \%$ & 1 & $5 \%$ \\
\hline 28. & 60 & 9 & $45 \%$ & 4 & $20 \%$ & 64. & 186 & 0 & $0 \%$ & 0 & $0 \%$ \\
\hline 29. & 70 & 2 & $10 \%$ & 4 & $20 \%$ & 65. & 188 & 15 & $75 \%$ & 0 & $0 \%$ \\
\hline 30. & 72 & 0 & $0 \%$ & 2 & $10 \%$ & 66. & 190 & 4 & $20 \%$ & 10 & $50 \%$ \\
\hline 31. & 73 & 5 & $25 \%$ & 0 & $0 \%$ & 67. & 200 & 5 & $25 \%$ & 9 & $45 \%$ \\
\hline 32. & 76 & 9 & $45 \%$ & 15 & $75 \%$ & 68. & 210 & 6 & $30 \%$ & 3 & $15 \%$ \\
\hline 33. & 78 & 1 & $5 \%$ & 0 & $0 \%$ & 69. & 220 & 9 & $45 \%$ & 9 & $45 \%$ \\
\hline 34. & 80 & 1 & $5 \%$ & 0 & $0 \%$ & 70. & 230 & 7 & $35 \%$ & 7 & $35 \%$ \\
\hline 35. & 82 & 0 & $0 \%$ & 0 & $0 \%$ & 71. & 240 & 11 & $55 \%$ & 17 & $85 \%$ \\
\hline 36. & 84 & 0 & $0 \%$ & 0 & $0 \%$ & & & & & & \\
\hline
\end{tabular}

and non-smokers were observed in the fractions of 24 , $32,127,140,163$ and $168 \mathrm{kDa}$, as their presence was found only in the serum of smokers. Certain protein fractions were more common in the serum of non-smokers. Prominent differences were found for the $76 \mathrm{kDa}$ protein fraction, which was absent in the serum of smok- 
Table 3. Comparison of protein fractions in women from the study group due to smoking

\begin{tabular}{|c|c|c|c|c|c|c|c|c|c|c|c|}
\hline \multirow{2}{*}{$\begin{array}{l}\text { No } \\
1 .\end{array}$} & \multirow{2}{*}{$\begin{array}{c}\text { The olecular } \\
\text { weight [kDa] }\end{array}$} & \multicolumn{2}{|c|}{$\begin{array}{c}\text { Smoking } \\
(N=8)\end{array}$} & \multicolumn{2}{|c|}{$\begin{array}{l}\text { Non-smoking } \\
(\mathrm{N}=12)\end{array}$} & \multirow{2}{*}{$\begin{array}{l}\text { No } \\
37 .\end{array}$} & \multirow{2}{*}{$\begin{array}{c}\text { The olecular } \\
\text { weight [kDa } \\
88\end{array}$} & \multicolumn{2}{|c|}{$\begin{array}{c}\text { Smoking } \\
(\mathrm{N}=8)\end{array}$} & \multicolumn{2}{|c|}{$\begin{array}{c}\text { Non-smoking } \\
(\mathrm{N}=12)\end{array}$} \\
\hline & & 7 & $88 \%$ & 11 & $92 \%$ & & & 7 & $88 \%$ & 11 & $92 \%$ \\
\hline 2. & 11 & 1 & $13 \%$ & 5 & $42 \%$ & 38. & 90 & 0 & $0 \%$ & 0 & $0 \%$ \\
\hline 3. & 12 & 5 & $63 \%$ & 5 & $42 \%$ & 39. & 92 & 0 & $0 \%$ & 0 & $0 \%$ \\
\hline 4. & 14 & 0 & $0 \%$ & 2 & $17 \%$ & 40. & 96 & 2 & $25 \%$ & 2 & $17 \%$ \\
\hline 5. & 15 & 8 & $100 \%$ & 11 & $92 \%$ & 41. & 98 & 0 & $0 \%$ & 0 & $0 \%$ \\
\hline 6. & 16 & 1 & $13 \%$ & 2 & $17 \%$ & 42. & 100 & 4 & $50 \%$ & 5 & $42 \%$ \\
\hline 7. & 17 & 5 & $63 \%$ & 5 & $42 \%$ & 43. & 107 & 3 & $38 \%$ & 1 & $8 \%$ \\
\hline 8. & 19 & 3 & $38 \%$ & 3 & $25 \%$ & 44. & 116 & 2 & $25 \%$ & 8 & $67 \%$ \\
\hline 9. & 20 & 0 & $0 \%$ & 0 & $0 \%$ & 45. & 127 & 1 & $13 \%$ & 0 & $0 \%$ \\
\hline 10. & 22 & 8 & $100 \%$ & 11 & $92 \%$ & 46. & 130 & 0 & $0 \%$ & 0 & $0 \%$ \\
\hline 11. & 23 & 0 & $0 \%$ & 0 & $0 \%$ & 47. & 132 & 3 & $38 \%$ & 9 & $75 \%$ \\
\hline 12. & 24 & 1 & $13 \%$ & 0 & $0 \%$ & 48. & 138 & 4 & $50 \%$ & 1 & $8 \%$ \\
\hline 13. & 25 & 0 & $0 \%$ & 0 & $0 \%$ & 49. & 140 & 1 & $13 \%$ & 0 & $0 \%$ \\
\hline 14. & 27 & 0 & $0 \%$ & 0 & $0 \%$ & 50. & 142 & 1 & $13 \%$ & 2 & $17 \%$ \\
\hline 15. & 28 & 6 & $75 \%$ & 11 & $92 \%$ & 51. & 144 & 0 & $0 \%$ & 2 & $17 \%$ \\
\hline 16. & 29 & 0 & $0 \%$ & 0 & $0 \%$ & 52. & 147 & 1 & $13 \%$ & 1 & $8 \%$ \\
\hline 17. & 32 & 1 & $13 \%$ & 0 & $0 \%$ & 53. & 150 & 2 & $25 \%$ & 1 & $8 \%$ \\
\hline 18. & 34 & 2 & $25 \%$ & 10 & $83 \%$ & 54. & 152 & 0 & $0 \%$ & 0 & $0 \%$ \\
\hline 19. & 36 & 0 & $0 \%$ & 0 & $0 \%$ & 55. & 157 & 4 & $50 \%$ & 3 & $25 \%$ \\
\hline 20. & 38 & 5 & $63 \%$ & 2 & $17 \%$ & 56. & 159 & 1 & $13 \%$ & 0 & $0 \%$ \\
\hline 21. & 40 & 0 & $0 \%$ & 0 & $0 \%$ & 57. & 160 & 2 & $25 \%$ & 9 & $75 \%$ \\
\hline 22. & 41 & 0 & $0 \%$ & 0 & $0 \%$ & 58. & 163 & 1 & $13 \%$ & 0 & $0 \%$ \\
\hline 23. & 42 & 0 & $0 \%$ & 0 & $0 \%$ & 59. & 168 & 2 & $25 \%$ & 0 & $0 \%$ \\
\hline 24. & 45 & 8 & $100 \%$ & 9 & $75 \%$ & 60. & 170 & 2 & $25 \%$ & 2 & $17 \%$ \\
\hline 25. & 48 & 1 & $13 \%$ & 3 & $25 \%$ & 61. & 172 & 1 & $13 \%$ & 3 & $25 \%$ \\
\hline 26. & 53 & 1 & $13 \%$ & 3 & $25 \%$ & 62. & 180 & 1 & $13 \%$ & 1 & $8 \%$ \\
\hline 27. & 56 & 5 & $63 \%$ & 5 & $42 \%$ & 63. & 182 & 0 & $0 \%$ & 0 & $0 \%$ \\
\hline 28. & 60 & 3 & $38 \%$ & 6 & $50 \%$ & 64. & 186 & 0 & $0 \%$ & 0 & $0 \%$ \\
\hline 29. & 70 & 0 & $0 \%$ & 2 & $17 \%$ & 65. & 188 & 6 & $75 \%$ & 9 & $75 \%$ \\
\hline 30. & 72 & 0 & $0 \%$ & 0 & $0 \%$ & 66. & 190 & 1 & $13 \%$ & 3 & $25 \%$ \\
\hline 31. & 73 & 3 & $38 \%$ & 2 & $17 \%$ & 67. & 200 & 2 & $25 \%$ & 3 & $25 \%$ \\
\hline 32. & 76 & 0 & $0 \%$ & 8 & $67 \%$ & 68. & 210 & 2 & $25 \%$ & 4 & $33 \%$ \\
\hline 33. & 78 & 0 & $0 \%$ & 1 & $8 \%$ & 69. & 220 & 3 & $38 \%$ & 6 & $50 \%$ \\
\hline 34. & 80 & 0 & $0 \%$ & 1 & $8 \%$ & 70. & 230 & 2 & $25 \%$ & 5 & $42 \%$ \\
\hline 35. & 82 & 0 & $0 \%$ & 0 & $0 \%$ & 71. & 240 & 4 & $50 \%$ & 7 & $58 \%$ \\
\hline 36. & 84 & 0 & $0 \%$ & 0 & $0 \%$ & & & & & & \\
\hline
\end{tabular}

ers, while its presence was observed in the most (8 of 12) non-smokers (Table 3 ). In a group of 20 women with recurrent miscarriages, 18 women had three miscarriages and 2 women had four. The prevalence of the most differentiating fractions $(27,28,36,38,53,132,172$ and
$188 \mathrm{kDa}$ ) was compared among women with a various number of miscarriages and among the reference group. It was noticed that the incidence of $53 \mathrm{kDa}$ and $172 \mathrm{kDa}$ protein fractions, predominant in the reference group, decreased in the study group along with the number of 
Table 4. Comparison of the occurrence of protein fractions among patients with different numbers of miscarriages

\begin{tabular}{|c|c|c|c|c|c|c|c|c|c|}
\hline \multirow[t]{3}{*}{ No } & \multirow{3}{*}{$\begin{array}{l}\text { The olecular } \\
\text { weight [kDa] }\end{array}$} & \multirow{3}{*}{$\begin{array}{c}\begin{array}{c}\text { Reference } \\
\text { group }\end{array} \\
\mathrm{N}=\mathbf{2 0}\end{array}$} & \multicolumn{2}{|c|}{ Study group } & \multirow[t]{3}{*}{ No } & \multirow{3}{*}{$\begin{array}{l}\text { The olecular } \\
\text { weight [kDa] }\end{array}$} & \multirow{3}{*}{$\begin{array}{c}\begin{array}{c}\text { Reference } \\
\text { group }\end{array} \\
\mathbf{N}=\mathbf{2 0}\end{array}$} & \multicolumn{2}{|c|}{ Study group } \\
\hline & & & $\mathrm{RM}=3$ & $\mathrm{RM}=4$ & & & & $\mathrm{RM}=3$ & $\mathrm{RM}=4$ \\
\hline & & & $N=18$ & $N=2$ & & & & $N=18$ & $N=2$ \\
\hline 1. & 10 & 20 & 16 & 2 & 37. & 88 & 12 & 17 & 1 \\
\hline 2. & 11 & 11 & 6 & 0 & 38. & 90 & 0 & 0 & 0 \\
\hline 3. & 12 & 6 & 8 & 2 & 39. & 92 & 1 & 0 & 0 \\
\hline 4. & 14 & 0 & 2 & 0 & 40. & 96 & 11 & 3 & 1 \\
\hline 5. & 15 & 20 & 17 & 2 & 41. & 98 & 1 & 0 & 0 \\
\hline 6. & 16 & 1 & 2 & 1 & 42. & 100 & 4 & 8 & 1 \\
\hline 7. & 17 & 0 & 9 & 1 & 43. & 107 & 4 & 4 & 0 \\
\hline 8. & 19 & 9 & 5 & 1 & 44. & 116 & 3 & 9 & 1 \\
\hline 9. & 20 & 0 & 0 & 0 & 45. & 127 & 5 & 1 & 0 \\
\hline 10. & 22 & 18 & 17 & 2 & 46. & 130 & 2 & 0 & 0 \\
\hline 11. & 23 & 0 & 0 & 0 & 47. & 132 & 4 & 11 & 1 \\
\hline 12. & 24 & 0 & 1 & 0 & 48. & 138 & 0 & 4 & 1 \\
\hline 13. & 25 & 0 & 0 & 0 & 49. & 140 & 2 & 1 & 0 \\
\hline 14. & 27 & 15 & 0 & 0 & 50. & 142 & 0 & 3 & 0 \\
\hline 15. & 28 & 1 & 15 & 2 & 51. & 144 & 3 & 2 & 0 \\
\hline 16. & 29 & 1 & 0 & 0 & 52. & 147 & 6 & 2 & 0 \\
\hline 17. & 32 & 0 & 1 & 0 & 53. & 150 & 7 & 3 & 0 \\
\hline 18. & 34 & 0 & 11 & 1 & 54. & 152 & 0 & 0 & 0 \\
\hline 19. & 36 & 20 & 0 & 0 & 55. & 157 & 0 & 6 & 1 \\
\hline 20. & 38 & 0 & 6 & 1 & 56. & 159 & 0 & 1 & 1 \\
\hline 21. & 40 & 2 & 0 & 0 & 57. & 160 & 3 & 11 & 0 \\
\hline 22. & 41 & 0 & 0 & 0 & 58. & 163 & 0 & 0 & 1 \\
\hline 23. & 42 & 0 & 0 & 0 & 59. & 168 & 0 & 2 & 0 \\
\hline 24. & 45 & 20 & 16 & 1 & 60. & 170 & 1 & 4 & 0 \\
\hline 25. & 48 & 0 & 3 & 1 & 61. & 172 & 17 & 4 & 0 \\
\hline 26. & 53 & 17 & 4 & 0 & 62. & 180 & 4 & 1 & 1 \\
\hline 27. & 56 & 3 & 8 & 2 & 63. & 182 & 1 & 0 & 0 \\
\hline 28. & 60 & 4 & 8 & 1 & 64. & 186 & 0 & 0 & 0 \\
\hline 29. & 70 & 4 & 2 & 0 & 65. & 188 & 0 & 14 & 1 \\
\hline 30. & 72 & 2 & 0 & 0 & 66. & 190 & 10 & 3 & 1 \\
\hline 31. & 73 & 0 & 4 & 1 & 67. & 200 & 9 & 4 & 1 \\
\hline 32. & 76 & 15 & 9 & 0 & 68. & 210 & 3 & 5 & 1 \\
\hline 33. & 78 & 0 & 1 & 0 & 69. & 220 & 9 & 8 & 1 \\
\hline 34. & 80 & 0 & 0 & 1 & 70. & 230 & 7 & 7 & 0 \\
\hline 35. & 82 & 0 & 0 & 0 & 71. & 240 & 17 & 10 & 1 \\
\hline 36. & 84 & 0 & 0 & 0 & & & & & \\
\hline
\end{tabular}

$\mathrm{RM}$ - recurrent miscarriage

miscarriages. These fractions were not detected in any patient with four miscarriages. The protein fractions of 27 and $36 \mathrm{kDa}$ were found exclusively in women who never had a miscarriage whereas the protein fraction of $38 \mathrm{kDa}$ was found in $35 \%$ of women with recurrent pregnancy loss. What is more, the 28,132 and $188 \mathrm{kDa}$ protein fractions were most frequent among women who miscarried three times (Table 4). 


\section{Discussion}

A comparative analysis of individual protein fractions present in the serum from women with recurrent miscarriages and the reference group was performed. The majority of determined 71 protein fractions were present in women from both groups, whereas the most noticeable differences were found for 7 fractions of 27 , 28, 36, 53, 132, 172 and $188 \mathrm{kDa}$. Interestingly, the $188 \mathrm{kDa}$ protein fraction was present in $75 \%$ of patients in the study group but was absent in women from the reference group. Similarly, the $28 \mathrm{kDa}$ protein fraction which occurred in only $5 \%$ of women from the reference group, was found in $85 \%$ of women with recurrent miscarriages. The $27 \mathrm{kDa}$ and $36 \mathrm{kDa}$ protein fractions occurred solely among the reference group. This fact could imply a protective effect of the aforementioned fractions on the successful course of pregnancy.

Among all the protein fractions determined, particular attention should be paid to the serum protein fraction of $36 \mathrm{kDa}$ present in all women with the successful course of pregnancy. According to the findings of Kim et al., who sought for potential biomarkers of recurrent miscarriages, the proteins of the $36 \mathrm{kDa}$ protein fraction are fragments of the inter-alpha-trypsin inhibitor heavy chain $\mathrm{H} 4$ and may be considered a potential marker of recurrent miscarriage. This protein fraction of $36 \mathrm{kDa}$ mass was highly expressed in patients with recurrent pregnancy loss.

The protein fractions of low- or mid-weight in serum from women with recurrent miscarriage may potentially play a role in the pathomechanism of this disorder. The presence of ITI-H4 protein fragments in the blood indicates an elevated level of enzymes that cleave these proteins and most likely are crucial for normal placental-uterine interaction. In order to separate protein fractions, the researchers used two-dimensional electrophoresis, and mass spectrometry and Western Blotting for protein fractions identification [8]. In our own study the $36 \mathrm{kDa}$ protein fraction was not detected in any patient with recurrent miscarriages, however, we found a $38 \mathrm{kDa}$ protein fraction present exclusively in women with recurrent pregnancy loss. The disparity in the obtained results may appear due to the use of different methods of protein identification and too few patients participating in the study. Nonetheless, the $36 \mathrm{kDa}$ and $38 \mathrm{kDa}$ protein fractions may be vital in cases of recurrent miscarriages.

In the presented study, the analysis of protein fractions among patients with recurrent pregnancy loss revealed that protein fractions of $24,32,127,140,163$ and $168 \mathrm{kDa}$ were found only among smokers. In $67 \%$ of non-smokers, $76 \mathrm{kDa}$ fraction was found. However, this fraction did not occur in any woman who smoked during pregnancy. Unfortunately, due to the lack of similar data obtained results cannot be compared to other investigating the impact of smoking on the composition of serum protein fractions among women with recurrent miscarriages.

Finally, the analysis of the seven fractions that most differentiated both groups was done among women with a various number of miscarriages $(\mathrm{RM}=3, \mathrm{RM}=4)$ and women from the reference group (Table 4). The 53 and $172 \mathrm{kDa}$ protein fractions, present in $85 \%$ of healthy women, seemed to dwindle with the number of miscarriages. These fractions were not found in any patient with four miscarriages. The 27 and $36 \mathrm{kDa}$ fractions occurred only in women from the reference group.

We are aware that the small number of women in both groups is the main limitation of this study, however, it features plenty of essential and valuable results. Due to the lack of similar publications comparing the individual composition of protein fractions that have an impact on the risk of recurrent pregnancy loss, it is not possible to undertake a broader discussion.

\section{Conclusion}

Some protein fractions present in the blood may potentially indicate the risk of miscarriages. There are protein fractions, which occurrence decreases with the number of miscarriages (53 and $172 \mathrm{kDa}$ ), what may influence the course of subsequent pregnancies.

\section{References}

1. Diejomaoh MFE. Recurrent spontaneous miscarriage is still a challenging diagnostic and therapeutic quagmire. Med Princ Pract. 2015 24 Suppl 1: 38-55, doi: 10.1159/000365973, indexed in Pubmed: 25428171.

2. Rekomendacje Polskiego Towarzystwa Ginekologicznego w zakresie wybranych patologii wczesnej ciąży oraz postępowania w ciąży po zapłodnieniu in vitro. Prz Menopauz, 2004; 6. : 8: 8-12.

3. Bręborowicz GH, Urban J, Skrzypczak J, et al. Położnictwo i ginekologia. Red. Wydawnictwo Lekarskie PZWL, Warszawa 2014; 1 85-91. : 160-162.

4. Lewicka M, Sulima M, Pyć M, et al. Charakterystyka poronień i prawa przysługujące kobiecie po stracie ciąży. Annales Academiae Medicae Stetinensis - Roczniki Pomorskiej Akademii Medycznej w Szczecinie, 2013; 59. ; 1: 123-129.

5. Malinowski A, Radwan M. Diagnostyka immunologiczna w poronieniach nawykowych: algorytm postępowania diagnostyczno-leczniczego z wykorzystaniem wyników badań własnych, Perinatol Neonatol Ginekol. 2011; 4 ; 4: 27-36.

6. Pereza N, Ostojić S, Smirčić A, et al. The -2549 insertion/deletion polymorphism in the promoter region of the VEGFA gene in couples with idiopathic recurrent spontaneous abortion. J Assist Reprod Genet. 2015; 32(12): 1789-1794, doi: 10.1007/s10815-015-0593-0, indexed in Pubmed: 26475697

7. Nagirnaja L, Palta P, Kasak L, et al. Structural genomic variation as risk factor for idiopathic recurrent miscarriage. Hum Mutat. 2014; 35(8): 972-982, doi: 10.1002/humu.22589, indexed in Pubmed: 24827138.

8. Kim MS, Gu BH, Song S, et al. ITI-H4, as a biomarker in the serum of recurrent pregnancy loss (RPL) patients. Mol Biosyst. 2011; 7(5): 1430-1440, doi: 10.1039/c0mb00219d, indexed in Pubmed: 21331437. 